\title{
1 Voltammetric determination of leucovorin in pharmaceutical 2 preparations using a boron-doped diamond electrode
}

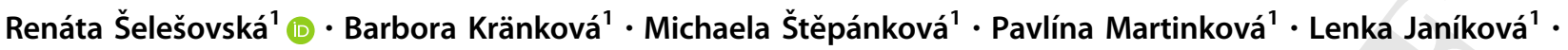
Jaromíra Chýlková ${ }^{\cdot}$ Tomáš Navrátil ${ }^{2}$

6 (C) Springer-Verlag GmbH Austria, part of Springer Nature 2018

\section{Abstract}

8 Method for voltammetric determination of leucovorin, a drug frequently applied to decrease some unfavorable effects of 9 anticancer drugs such as methotrexate or to increase the therapeutic effect of 5-fluorouracil, has been developed employing 10 a bare boron-doped diamond electrode. It is the first method for leucovorin determination based on its electrochemical oxidation. Although at least three anodic and three cathodic voltammetric peaks could be recorded under the used conditions, only the anodic response situated at about $+900 \mathrm{mV}$ (vs. saturated $\mathrm{Ag} / \mathrm{AgCl}$ electrode) was suitable, namely due to its shape and position, for analytical purposes. Using differential pulse voltammetry with optimized parameters and supporting electrolyte of $\mathrm{pH} \mathrm{3,} \mathrm{the} \mathrm{linear} \mathrm{dynamic} \mathrm{range} \mathrm{of} \mathrm{leucovorin} \mathrm{determination} \mathrm{was} \mathrm{recorded} \mathrm{from} 0.15$ to $25 \mu \mathrm{mol} \mathrm{dm}{ }^{-3}$. Under such conditions, low limit of quantification of $0.050 \mu \mathrm{mol} \mathrm{dm}^{-3}$ and limit of detection of $0.015 \mu \mathrm{mol} \mathrm{dm}{ }^{-3}$ as well was reached. Relative standard deviation calculated from 11 repeated measurements amounted to $0.7 \%$ and calculated from five repeated determinations amounting less than $3.0 \%$. Applicability of the developed method was verified by repeated analysis of the pharmaceutical preparation with excellent results (recovery 98.7-102.8\%, relative standard deviation $1.81 \%$ ).

\section{Graphical abstract}

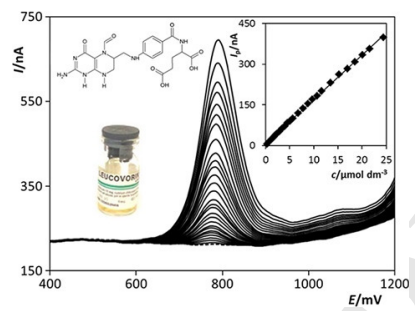

Keywords Boron-doped diamond electrode - Determination - Folinic acid - Leucovorin · Pharmaceutical samples . Voltammetry

\section{Introduction}

Leucovorin (LV) known as folinic acid (5-formyltetrahydrofolate, 5-formyl- $\mathrm{H}_{4}$ folate), which is target analyte of the present paper, is depicted in Fig. 1. It occurs as a racemic mixture, but only its L-form is pharmaceutically active. LV is formed by reduction of folic acid (FA). From a biochemical point of view, LV is a 5-formyl derivative of tetrahydrofolic acid $[1,2]$. It has been applied as a drug

\begin{tabular}{|l|ll|} 
Journal : Large 706 & Dispatch : 11-4-2018 & Pages : 8 \\
Article No. : 2200 & $\square$ LE & $\square$ TYPESET \\
MS Code : MCCM-D-18-00085 & $\sim_{\text {CP }}$ & $\checkmark$ DISK \\
\hline
\end{tabular}


<smiles></smiles>

Fig. 1 Structural formula of leucovorin

which is able to decrease unfavorable effects of pyrimethamine or immune system suppressant methotrexate (MTX) [3]. Furthermore, LV in high doses can find its utilization in simultaneous administration with 5-fluorouracil to treat gastric and colorectal carcinoma $[4,5]$.

As it is evident from the above-mentioned information, it is highly important to determine LV in pharmaceutical products and in body fluids. Various analytical methods have been used for these purposes up to now. From nonelectrochemical methods application of mass spectrometry for these purposes can be mentioned [6]. As in other cases, different separation methods have been used most frequently, e.g., high performance liquid chromatography (HPLC) with UV detection [7], with fluorescence detection [8], or with gradient elution with following dual UV-fluorescence detection $[9,10]$. Pre-separation of an analyzed sample using solid-phase extraction has been described in literature as well $[6,7,11]$. LV levels in urine or serum samples without pre-separation steps have been also analyzed using spectrophotometric techniques $[12,13]$. Some authors have reported the application of capillary zone electrophoresis [14, 15] or of kinetic fluorimetry [16] for $\mathrm{LV}$ determination.

On the other hand, only a little attention has been recently paid to the application of electroanalytical methods of LV determination. Using these methods (mainly voltammetry and polarography) FA and its derivatives and metabolites can be easily determined. Because these compounds are electrochemically reducible and oxidizable, respectively, voltammetric techniques could be employed for their analysis. Utilization of the different electrodes have been described in literature sources, e.g., modified carbon electrodes $[17,18]$, multi-walled carbon nanotubemodified gold electrodes [19], single-walled carbon nanotube-ionic liquid paste electrode $[18,20]$, mercury electrodes [21], as well as amalgam electrodes [22, 23]. MTX can be analyzed non-electrochemically (e.g., using HPLC [9] as well as electrochemically using different electrodes (e.g., amalgam or boron-doped diamond electrodes) $[24,25]$ too. Electrochemical behavior and determination of LV was described in details many years ago using dropping mercury electrode (DME) [26] and all of the following works deal also with the utilization of mercury [27] or silver solid amalgam electrodes (AgSAE) [28].

$\mathrm{LV}$ reaction mechanisms were described in detail in, e.g., [26-28]. Three oxidation signals were recorded on DME [26]. Heyrovský et al. [27] observed a peak pair (anodic peak at about $-800 \mathrm{mV}$, cathodic peak at about $-950 \mathrm{mV}$ ) on hanging mercury drop electrode (HMDE). Two voltammetric signals corresponding to the oxidation of tetrahydropteridine ring was registered at potentials of -150 and of $0 \mathrm{mV}$. The oxidation products, which are adsorbable at the electrode surface, can be reduced at about $-400 \mathrm{mV}$. This signal was successfully used for LV determination on HMDE [27] as well as on AgSAE [28].

All the above-mentioned voltammetric methods of LV determination are based on its reduction. In the present paper, electrochemical oxidation of LV was studied and the procedure of LV determination on boron-doped diamond electrode (BDDE) was developed. Electrodes based on boron-doped diamond film have been so far successfully applied in the voltammetric analysis of various biologically active compounds, e.g., [29-32]. In the past, there was published the determination of FA [33] and MTX [25] on a bare BDDE using differential pulse voltammetry (DPV). Therefore, this paper focuses on development and verification of an electrochemical method of LV determination on this electrode too. Optimum conditions for DPV determination of LV were found and proposed and this sensitive method was tested by analysis of LV in a commercially available pharmaceutical preparation.

\section{Results and discussion}

\section{Voltammetric behavior of leucovorin in dependence on $\mathrm{pH}$}

First, cyclic voltammetry (CV) on a bare BDDE [supporting electrolyte Britton-Robinson buffer (BRB)] was utilized to characterize recordable and evaluable voltammetric signals of LV and influence of $\mathrm{pH}$ on the shape, position, and number of $\mathrm{CV}$ peaks or more correctly waves (Fig. 2). It was found that LV provides two anodic (oxidation) peaks [at $\mathrm{pH} 5$ at about $+900 \mathrm{mV}$ (Fig. 2, peak 1) and at about $+1500 \mathrm{mV}$ (Fig. 2, peak 2)] and two cathodic (reduction) peaks (at $\mathrm{pH} 5$ at about $+800 \mathrm{mV}$, peak $1^{\prime}$, and $+1300 \mathrm{mV}$, peak $2^{\prime}$ ) in a wide range of $\mathrm{pH}$ 1-10. Differences between peak potentials of the more positive as well as of the more negative pair of peaks have confirmed their quasi-reversible characters. Presence of these two oxidation and two reduction pairs, respectively, corresponds with earlier published results recorded on DME [26], HMDE [27], or on two modifications of AgSAE

$\begin{array}{lll}\text { Journal : Large 706 } & \text { Dispatch : 11-4-2018 } & \text { Pages : } 8 \\ \text { Article No. : } \mathbf{2 2 0 0} & \square \text { LE } & \square \text { TYPESET } \\ \text { MS Code : } \quad \text { MCCM-D-18-00085 } & \checkmark \text { CP } & \checkmark \text { DISK }\end{array}$




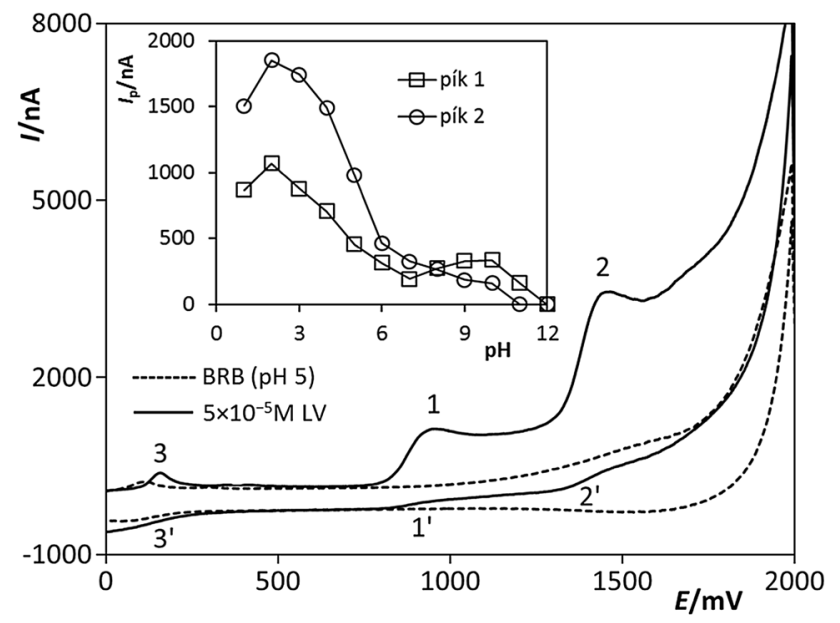

Fig. 2 Cyclic voltammograms of LV recorded on BDDE. Method: $\mathrm{CV}$, supporting electrolyte: $\mathrm{BRB}(\mathrm{pH}$ 5.0) (dashed line), initial potential $\left(E_{\text {in }}\right)=0 \mathrm{mV}$, switch potential $\left(E_{\mathrm{sw}}\right)=+2000 \mathrm{mV}$, scan rate $(v)=100 \mathrm{mV} \mathrm{s}^{-1}, \quad c_{\mathrm{LV}}=50 \mu \mathrm{mol} \mathrm{\textrm {dm } ^ { - 3 }}$ (solid line); inset: dependences of chosen anodic peak heights on supporting electrolyte $\mathrm{pH}$ values

[28]. Moreover, one pair of small and hardly evaluable applied scan rates $(v)$ was investigated and the obtained curves are displayed in Fig. 3. In the case of all anodic LV signals, almost ideal linear dependences of $I_{\mathrm{p}}$ on the square root of the scan rate (in the range from 25 to $500 \mathrm{mV} \mathrm{s}^{-1}$ ) were obtained [correlation coefficients $(r)=0.997,0.996$, and 0.998; Eqs. (1)-(3)]. According to these results, it was possible to conclude that all observed processes were diffusion controlled.

$$
\begin{aligned}
& I_{\mathrm{p}}[\mathrm{nA}]=(20.60 \pm 0.39) v^{1 / 2}\left[(\mathrm{mV} / \mathrm{s})^{1 / 2}\right]+(342.5 \pm 6.4), \\
& \quad r=0.997
\end{aligned}
$$

$I_{\mathrm{p}}[\mathrm{nA}]=(59.6 \pm 1.1) v^{1 / 2}\left[(\mathrm{mV} / \mathrm{s})^{1 / 2}\right]+(258 \pm 19)$,
$\quad r=0.996$

$$
\begin{aligned}
& I_{\mathrm{p}}[\mathrm{nA}]=(13.83 \pm 0.21) v^{1 / 2}\left[(\mathrm{mV} / \mathrm{s})^{1 / 2}\right]-(14.0 \pm 3.5), \\
& \quad r=0.998
\end{aligned}
$$

The realized $\log -\log$ analyses were linear too $(r=0.997,0.998$, and 0.999), but they revealed that the value 0.5 was not included in any of all calculated slopes of these $\log -\log$ dependences. In the case of signals 1 and 2 , the slope values $\left[0.2117 \pm 0.0042 \log \left(\mathrm{nA} \mathrm{s} \mathrm{mV}^{-1}\right)\right.$, Eq. (4) and $0.3747 \pm 0.0054 \log \left(\mathrm{nA} \mathrm{s} \mathrm{mV}^{-1}\right)$, Eq. (5)] were between 0 and 0.5 . Therefore, some kinetically controlled process which was independent of scan rate and which participated in a controlling of both registered processes should be taken into account. The slope value of peak $3\left[0.5326 \pm 0.0068 \log \left(\mathrm{nA} \mathrm{s} \mathrm{mV}^{-1}\right)\right.$, Eq. (6)] is very close to the theoretical value 0.5 , which can imply simple diffusion controlled process.

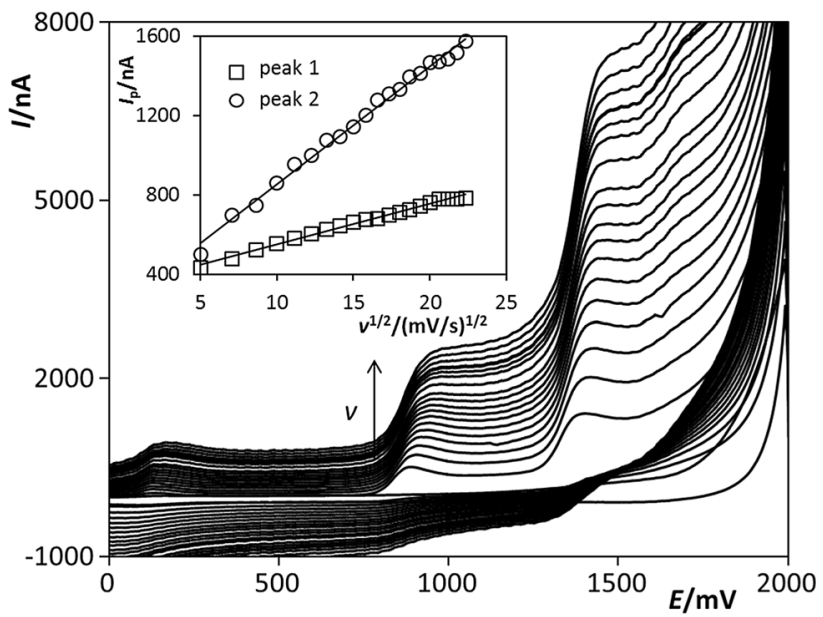

Fig. 3 Cyclic voltammograms of leucovorin obtained on BDDE in dependence on scan rate. Method: $\mathrm{CV}$, supporting electrolyte: $\mathrm{BRB}$ (pH 5.0), $E_{\text {in }}=0 \mathrm{mV}, E_{\mathrm{sw}}=+2200 \mathrm{mV}, v=25-500 \mathrm{mV} \mathrm{s}^{-1}, c_{\mathrm{LV}}$. $=50 \mu \mathrm{mol} \mathrm{dm}{ }^{-3}$; inset: dependences of peak heights on square root of scan rates for LV peak 1 and 2, respectively

\begin{tabular}{|l|lll|}
\hline & Journal : Large 706 & Dispatch : 11-4-2018 & Pages : $\mathbf{8}$ \\
Article No. : 2200 & $\square$ & LE & $\square_{\text {TYPESET }}^{\text {TYS }}$ \\
\hline
\end{tabular}




$$
\begin{aligned}
\log \left(I_{\mathrm{p}}[\mathrm{nA}]\right)= & (0.2117 \pm 0.0042) \log (v[(\mathrm{mV} / \mathrm{s})]) \\
& +(2.3230 \pm 0.0010), \\
r=0.997 &
\end{aligned}
$$

184

$$
\begin{aligned}
\log \left(I_{\mathrm{p}}[\mathrm{nA}]\right)= & (0.3747 \pm 0.0054) \log (v[(\mathrm{mV} / \mathrm{s})])+(2.185 \\
& \pm 0.013), \\
r=0.998 &
\end{aligned}
$$

$$
\begin{aligned}
\log \left(I_{\mathrm{p}}[\mathrm{nA}]\right)= & (0.5326 \pm 0.0068) \log (v[(\mathrm{mV} / \mathrm{s})])+(1.031 \\
& \pm 0.016) \\
r=0.999 &
\end{aligned}
$$

Finally, for purposes of LV determination, DPV method was applied due to the generally know higher sensitivity of the pulse voltammetric techniques. The anodic DPV peak located at about $+850 \mathrm{mV}$ was used in this respect considering its favorable position and shape. Firstly, it was confirmed that $I_{\mathrm{p}}$ dependence on $\mathrm{pH}$ brought us the same conclusions as it was found in the case of $\mathrm{CV}$ and the obtained curves are depicted in Fig. 4. Considering clarity of Fig. 4, voltammograms recorded in media of $\mathrm{pH}$ values from 1 to 5 are displayed. The highest current peak 1 was observed in BRB of $\mathrm{pH} 2$. Probably due to the higher DPV sensitivity, we were able to reveal that on the positive shoulder of the investigated peak, small and a bit positively situated peak was registered in the most acidic solutions (Fig. 4). This small peak decreased with increasing $\mathrm{pH}$

\section{Determination of leucovorin in model solutions}

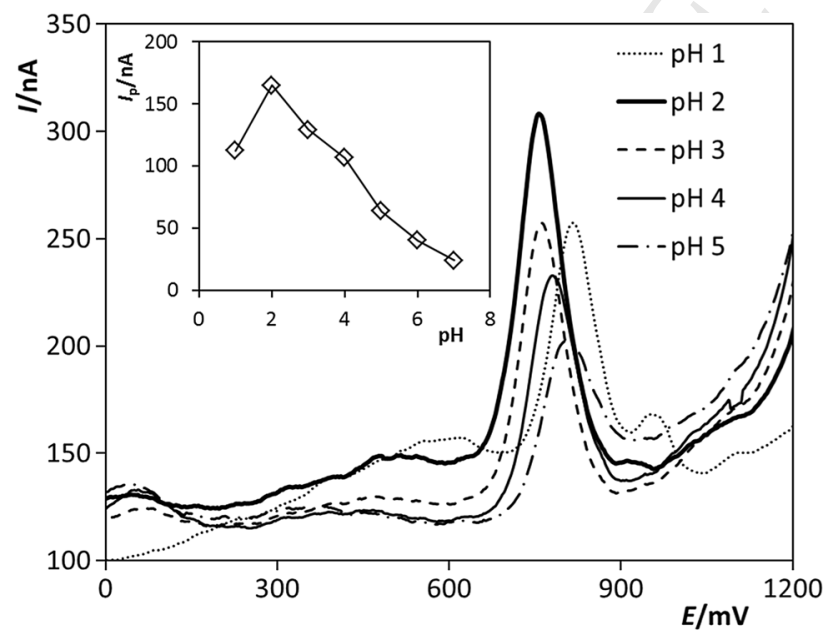

Fig. 4 DP voltammograms of LV obtained on BDDE in dependence on $\mathrm{pH}$. Method: DPV, supporting electrolyte: BRB (pH 1-5), $E_{\text {in }}=0$ $\mathrm{mV}, E_{\mathrm{fin}}=+1300 \mathrm{mV}, v=25 \mathrm{mV} \mathrm{s}^{-1}$, pulse height $=+50 \mathrm{mV}$, pulse width $=70 \mathrm{~ms}, c_{\mathrm{LV}}=10 \mu \mathrm{mol} \mathrm{dm}{ }^{-3}$; inset: dependence of $I_{\mathrm{p}}$ (of the DPV anodic peak located at about $+850 \mathrm{mV}$ ) on $\mathrm{pH}$ of supporting electrolyte value of the supporting electrolyte and in solutions of $\mathrm{pH} \geq 3$ completely disappeared. The presence of this peak affected negatively repeatability of recorded signals. Therefore, contrary to the widely accepted theory that most of the compounds are hardly adsorbable on the surface of a BDDE, in our case, presumably, some of the reaction intermediate was adsorbed on the used polycrystalline diamond surface in acidic media $(\mathrm{pH}<3)[34,35]$.

The obtained findings were confirmed by experiments, with the results depicted in Fig. 5. The most significant DPV anodic peak 1 decreased monotonously with an increasing number of repetitions. Simultaneously, smaller and about $130 \mathrm{mV}$ more positively situated peak, increased monotonously with an increasing number of repetitions. However, no such positively situated peak was observed at pH 3 or higher and peak 1 exhibited almost constant height (Fig. 5, inset). Nevertheless, the small difference between background current of supporting electrolyte and background current under LV presence (Figs. 2, 5) indicated hypothetical adsorption on the diamond surface. The results of repeatability of $\mathrm{LV}$ peak current $\left(c_{\mathrm{LV}}\right.$ $=10 \mathrm{~mol} \mathrm{dm}^{-3}$ in BRB with $\mathrm{pH}$ values from 2 to 5) are summarized in Table 1 . While the repeatability of the signal was poor in the BRB of $\mathrm{pH} 2\left(\mathrm{RSD}_{11}=8.3 \%\right)$, the results proved to be significantly improved in less acidic media. In the case of $\mathrm{pH} 3, \mathrm{RSD}_{11}$ of $I_{\mathrm{p}}$ values amounted to $1.9 \%$, and the decrease of average $I_{\mathrm{p}}$ was about $15 \%$ only. Therefore, this $\mathrm{pH}$ value of the supporting electrolyte was chosen as the most suitable for the analytical purposes, i.e., for LV determination.

The following experiments were focused on the optimization of basic parameters of DPV and are illustrated in

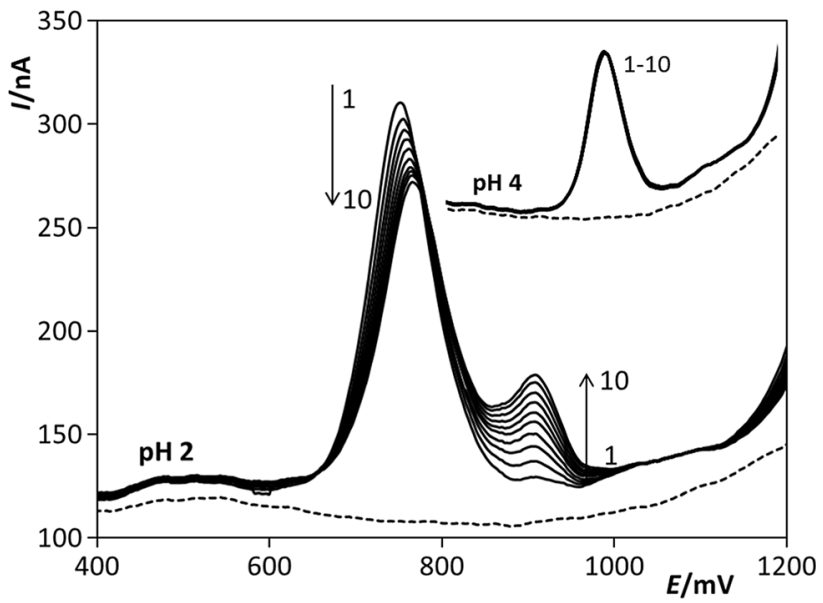

Fig. 510 times repeated DP voltammograms of LV recorded using BDDE in BRB (pH 2.0). Inset: 10 times repeated voltammograms of $\mathrm{LV}$ recorded using $\mathrm{BDDE}$ in $\mathrm{BRB}(\mathrm{pH}$ 4.0). Method: DPV, $E_{\text {in }}=0 \mathrm{mV}, E_{\text {fin }}=+1200 \mathrm{mV}, v=25 \mathrm{mV} \mathrm{s}^{-1}$, pulse height $=+$ $50 \mathrm{mV}$, pulse width $=50 \mathrm{~ms}, c_{\mathrm{LV}}=10 \mu \mathrm{mol} \mathrm{dm}{ }^{-3}$ (solid lines), supporting electrolyte of $\mathrm{pH} 2$ and 4 , respectively (dashed lines)

\begin{tabular}{|l|lll|}
\hline & Journal : Large 706 & Dispatch : 11-4-2018 & Pages : 8 \\
Article No. : 2200 & $\square_{\mathrm{CP}}^{\mathrm{LE}}$ & $\square_{\text {TISK }}^{\text {TYPET }}$ \\
\hline
\end{tabular}


Table 1 Repeatability of DPV measurement of $10 \mu \mathrm{mol} \mathrm{dm}{ }^{-3}$ $\mathrm{LV}$ in dependence on $\mathrm{pH}$

\begin{tabular}{lcl}
\hline $\mathrm{PH}$ & $I_{\mathrm{p}} / \mathrm{nA}$ & $\mathrm{RSD}_{10} / \%$ \\
\hline 2 & $161.4 \pm 8.8$ & 8.3 \\
3 & $132.8 \pm 1.7$ & 1.9 \\
4 & $107.09 \pm 0.62$ & 0.9 \\
5 & $64.53 \pm 0.83$ & 1.9 \\
\hline
\end{tabular}

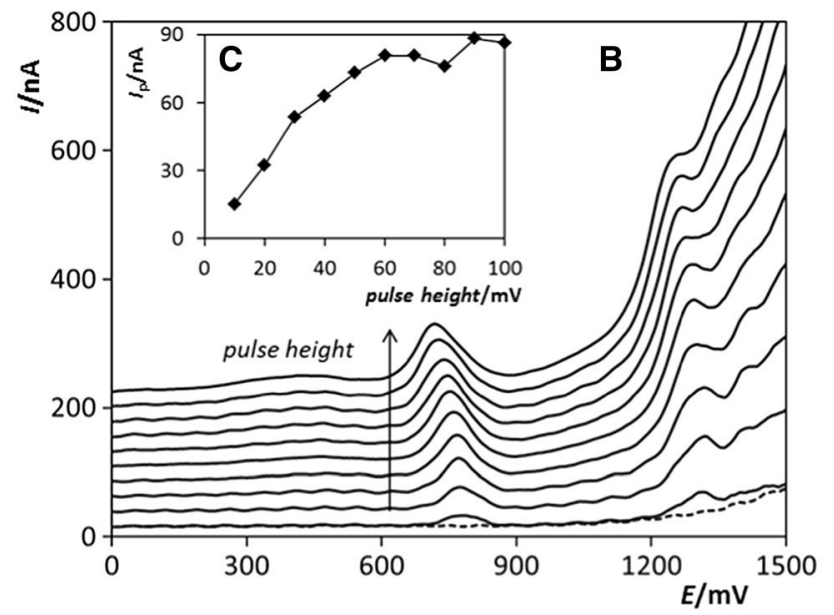

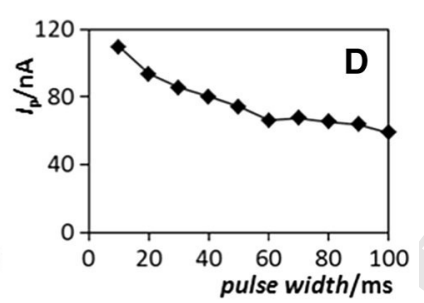

Fig. 6 Optimization of DPV parameters: a dependence of $I_{\mathrm{p}}(\mathrm{LV})$ on $v$, b DP voltammograms of LV in dependence on pulse height, c dependence of $I_{\mathrm{p}}(\mathrm{LV})$ on pulse height, $\mathbf{d}$ dependence of $I_{\mathrm{p}}(\mathrm{LV})$ on pulse width. Method: DPV, supporting electrolyte: BRB (pH 3), $E_{\text {in }}=0 \mathrm{mV}, E_{\text {fin }}=+1500 \mathrm{mV}, v=10-100 \mathrm{mV} \mathrm{s}^{-1}(\mathbf{a}), 40 \mathrm{mV} \mathrm{s}^{-1}$ $(\mathbf{b}, \mathbf{c}, \mathbf{d})$, pulse height $=+50 \mathrm{mV}(\mathbf{a}, \mathbf{d}),+10-100 \mathrm{mV}(\mathbf{b}, \mathbf{c})$, pulse width $=50 \mathrm{~ms}(\mathbf{a}, \mathbf{b}, \mathbf{c}), 10-100 \mathrm{~ms}(\mathbf{d}), c_{\mathrm{LV}}=5.0 \mu \mathrm{mol} \mathrm{dm}{ }^{-3}$
Fig. 6. All measurements were realized in LV solution with concentration of $5.0 \mu \mathrm{mol} \mathrm{dm}{ }^{-3}$. Tested parameters were changed in these ranges: $v-10-100 \mathrm{mV} \mathrm{s}^{-1}$, pulse height- $+(10-100) \mathrm{mV}$, pulse width $-10-100 \mathrm{~ms}$ and were optimized as follows: $v=40 \mathrm{mV} \mathrm{s}^{-1}$, pulse height $=+50 \mathrm{mV}$, pulse width $=20 \mathrm{~ms}$ (where the current values were registered and averaged in last $20 \mathrm{~ms}$ ). These parameters were used for all subsequent DPV measurements.

The linear dynamic range of LV determination was found from 0.15 to $25 \mu \mathrm{mol} \mathrm{dm}{ }^{-3}$. The concentration dependences were linear in different smaller subranges too (summary in Table 2, example in Fig. 7). Reached correlation coefficients were higher than 0.9991 in all cases and the slope values were almost identical. From the registered parameters, it was possible to calculate limit of detection
Table 2 Statistical parameters of LV concentration dependences registered under conditions given in the legend for Fig. 7

\begin{tabular}{|c|c|c|c|}
\hline$c / \mu \mathrm{mol} \mathrm{dm}{ }^{-3}$ & Slope $/ \mathrm{nA} \mathrm{dm}{ }^{3} \mu \mathrm{mol}^{-1}$ & Intercept/nA & $r$ \\
\hline $1.0-11.0$ & $16.389 \pm 0.062$ & $0.61 \pm 0.42$ & 0.9999 \\
\hline $0.25-2.8$ & $17.19 \pm 0.25$ & $0.55 \pm 0.42$ & 0.9991 \\
\hline $0.15-1.7$ & $17.201 \pm 0.084$ & $0.089 \pm 0.086$ & 0.9999 \\
\hline $0.3-24.5$ & $16.392 \pm 0.03)$ & $5.4976 \pm 4.1$ & 0.9996 \\
\hline
\end{tabular}

Confidence intervals calculated at the level of significance $\alpha=0.05$

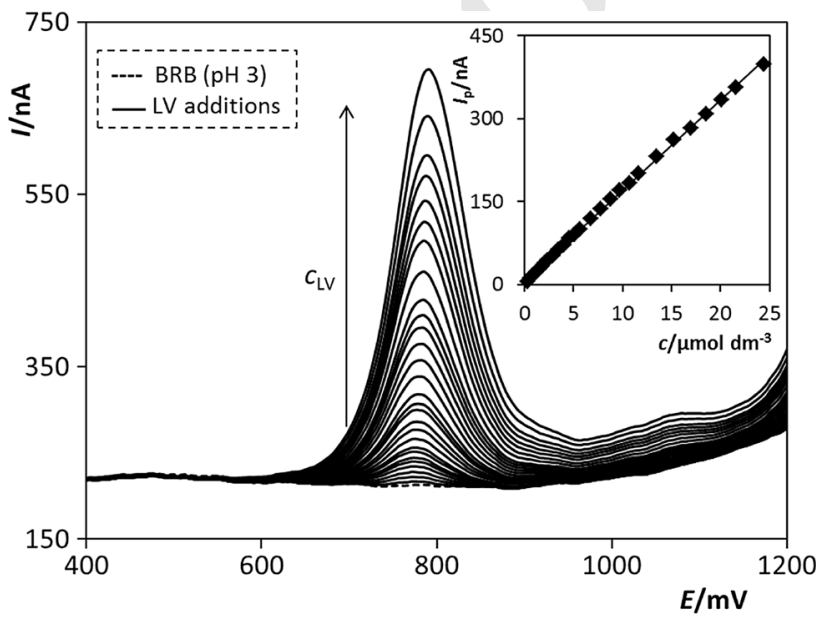

Fig. 7 DP voltammograms of LV obtained on BDDE in dependence on LV concentration. Method: DPV, supporting electrolyte: BRB ( $\mathrm{pH}$ 3), $E_{\mathrm{in}}=0 \mathrm{mV}, E_{\mathrm{fin}}=+1200 \mathrm{mV}, v=40 \mathrm{mV} \mathrm{s}^{-1}$, pulse height $=$ $+50 \mathrm{mV}$, pulse width $=20 \mathrm{~ms}, c_{\mathrm{LV}}=0.30-24.5 \mu \mathrm{mol} \mathrm{dm}^{-3}$; inset: dependence of $I_{\mathrm{p}}$ on $\mathrm{LV}$ concentration

$(\mathrm{LOD})=0.015 \mu \mathrm{mol} \mathrm{\textrm {dm } ^ { - 3 }}$ and limit of quantification (LOQ) $0.050 \mu \mathrm{mol} \mathrm{dm}{ }^{-3}$, respectively. The values confirmed applicability of the proposed technique also for detection and determination of LV on the low concentration level.

To confirm the applicability of the suggested method for LV determination in a simple model solution of BRB, three solutions of different concentration levels were prepared: 10.0, 3.0, and $0.3 \mu \mathrm{mol} \mathrm{dm}{ }^{-3}$. Each determination was five

Table 3 Results of five repeated LV determinations in model BRB solutions

\begin{tabular}{lccl}
\hline Added $/ \mu \mathrm{mol} \mathrm{dm}^{-3}$ & Found $/ \mu \mathrm{mol} \mathrm{dm}{ }^{-3}$ & Recovery$/ \%$ & $\mathrm{RSD}_{5} / \%$ \\
\hline 10.0 & $10.10 \pm 0.17$ & $98.0-105.0$ & 2.57 \\
3.0 & $3.030 \pm 0.035$ & $98.3-102.6$ & 1.74 \\
0.3 & $0.3000 \pm 0.0029$ & $99.0-102.6$ & 1.46 \\
\hline
\end{tabular}

Used parameters are given in the legend for Fig. 7. Confidence intervals calculated at the level of significance $\alpha=0.05$

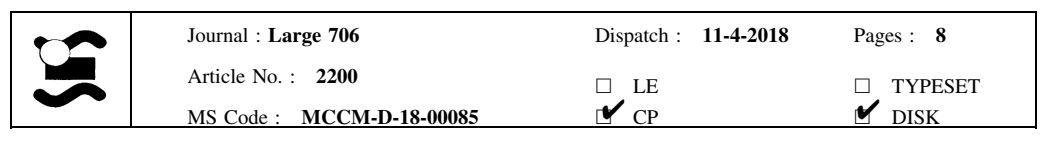


times repeated. The achieved results are summarized in Table 3. It could be concluded that all found LV concentrations corresponded to added LV amounts $(\alpha=0.05)$, reached LV recovery amounted to from 98.0 to $105.0 \%$ and RSD calculated from all five repeated determinations $\left(\mathrm{RSD}_{5}\right)$ was in all of the tested concentration levels $<2.6 \%$.

\section{Determination of leucovorin in pharmaceutical preparation}

Finally, the applicability of the above described and developed DPV method of LV determination was verified by analysis of this analyte in a commercial preparation "Leucovorin CA LACHEMA 10". This preparation was an injection powder with declared LV content of $10 \mathrm{mg}$ per vial. The analyzed solution was prepared by dissolving of LV powder in distilled water according to the producer instructions and as it is described in the "Experimental" part of this manuscript in the chapter "Pharmaceutical sample analysis". The LV determination was realized using the standard addition method and repeated five times (Fig. 8). The determined amount of LV $10.08 \pm 0.12 \mathrm{mg}$ of LV per vial was in good agreement with declared LV content of $10 \mathrm{mg}$ per vial $(\alpha=0.05)$. RSD of five repeated determinations reached $1.81 \%$ and recovery $98.7-102.8 \%$. Therefore, it could be summarized that the suggested method is suitable for analysis of pharmaceutical samples without insertion of any preparation technique. The determination has not been disturbed by the presence either of sodium chloride, sodium hydroxide (present in this preparation in approximately comparable amounts with LV, i.e.,

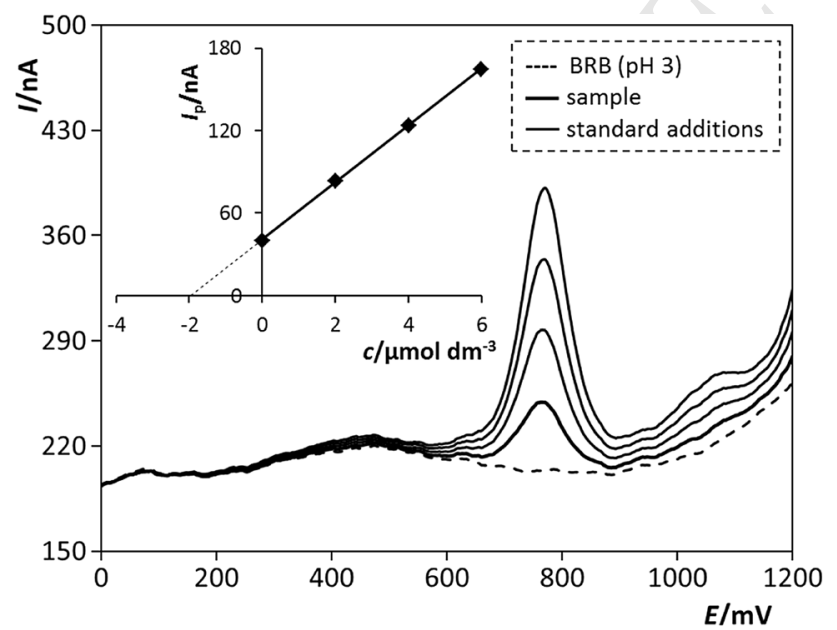

Fig. 8 DPV determination of LV in a pharmaceutical preparation sample using BDDE. Method: DPV, supporting electrolyte: BRB (pH 3), $E_{\text {in }}=0 \mathrm{mV}, E_{\text {fin }}=+1200 \mathrm{mV}, v=40 \mathrm{mV} \mathrm{s}^{-1}$, pulse height $=$ $+50 \mathrm{mV}$, pulse width $=20 \mathrm{~ms}$, standard additions: $V=20 \mathrm{~mm}^{3}$, $c_{\mathrm{LV}}=1 \mathrm{mmol} \mathrm{dm}{ }^{-3}$; inset: graphical evaluation of standard addition method
10 and $8 \mathrm{mg}$, respectively, cf. $10 \mathrm{mg}$ of LV), or of any of other pharmaceutical fillers used.

\section{Conclusion}

It was confirmed that a bare BDDE, as a working electrode, could be used for voltammetric detection and determination of LV based on its electrochemical oxidation. BRB, particularly of $\mathrm{pH} 3$, proved to be suitable supporting electrolyte. Using either CV or DPV, two anodic and two cathodic significant and well developed voltammetric LV peaks could be recorded (at about +850 and $+1450 \mathrm{mV}$ ) and one pair of small and hardly evaluable peaks (at about $+150 \mathrm{mV}$ ). Finally, the DPV anodic peak located at about $+850 \mathrm{mV}$ was found to be suitable for analytical purposes. Its height was the most sensitive to LV concentration changes, it was the best developed and reproducible under optimized conditions. The highest and simultaneously the most reproducible peak was recorded in BRB of $\mathrm{pH} 3$, which was chosen for all other analysis. The DPV method was applied for determination of LV in deionized water (linear dynamic range from 0.15 to $25 \mu \mathrm{mol} \mathrm{dm}^{-3}$, LOQ $0.050 \mu \mathrm{mol} \mathrm{dm}{ }^{-3}$, and LOD $0.015 \mu \mathrm{mol} \mathrm{dm}{ }^{-3}$ ). Similarly, determination of LV in a commercial pharmaceutical preparation "LEUCOVORIN CA LACHEMA 10" was found to be successful considering the achieved results, which were consistent with the declared LV content (recovery $98.7-102.8 \%$ ).

It could be concluded, that our proposed method represent simple but very precise and sensitive tool for determination of the important bioactive compound $\mathrm{LV}$ in the pharmaceutical samples. It is the first voltammetric method for LV determination based on its oxidation and simultaneously the first described method using non-mercury working electrode.

\section{Experimental}

Chemicals

The $1 \mathrm{mmol} \mathrm{dm}{ }^{-3}$ solution of LV was prepared by dissolving of the appropriate amount of calcium folinate, European Pharmacopoeia (EP) Reference Standard (Sigma-Aldrich, Czech Republic) in distilled water and stored in the dark at $+4{ }^{\circ} \mathrm{C}$. The analyzed solutions were prepared daily fresh by dilution of the BRB stock solution.

All chemicals used to prepare stock solutions and basic electrolytes were of p.a. purity. BRBs of $\mathrm{pH}$ value from 2.0 to 12.0 were prepared from an alkaline component of $0.2 \mathrm{~mol} \mathrm{dm}^{-3} \mathrm{NaOH}$ and an acidic component consisting of $0.04 \mathrm{~mol} \mathrm{dm}{ }^{-3} \mathrm{H}_{3} \mathrm{PO}_{4}, 0.04 \mathrm{~mol} \mathrm{dm}{ }^{-3} \mathrm{H}_{3} \mathrm{BO}_{3}$, and

\begin{tabular}{|l|lll|}
\hline & Journal : Large 706 & Dispatch : 11-4-2018 & Pages : 8 \\
Article No. : 2200 & $\square$ LE & $\square$ \\
MS Code : MCCM-D-18-00085 & $\checkmark_{\mathrm{CP}}^{\text {TYPESET }}$ \\
\hline
\end{tabular}


$0.04 \mathrm{~mol} \mathrm{dm}^{-3} \mathrm{CH}_{3} \mathrm{COOH}$ (all these chemicals Lachema, Czech Republic). Solutions of $\mathrm{H}_{2} \mathrm{SO}_{4}$ were prepared by dilution of concentrated $96 \% \mathrm{H}_{2} \mathrm{SO}_{4}$, p.a. (Ing. Petr ŠvecPENTA, Czech Republic) by deionized water. Deionized water (conductivity $<0.05 \mu \mathrm{S} \mathrm{cm}{ }^{-1}$ ) produced by MilliQ-Gradient, Millipore, Prague, Czech Republic, was used for all described measurements.

The pharmaceutical preparation in powder form for injection solution preparation "LEUCOVORIN CA LACHEMA 10" was purchased from Pliva-Lachema, Brno. Declared content of calcium folinate pentahydrate was $12.7 \mathrm{mg}$ (corresponding to $10 \mathrm{mg}$ of $\mathrm{LV}$ in $1 \mathrm{~cm}^{3}$ of prepared injection solution). Moreover, this preparation contained sodium chloride $(10 \mathrm{mg})$ and sodium hydroxide (8 mg).

\section{Instrumentation}

The Eco-Tribo Polarograph (Polaro-Sensors, Czech Republic) controlled by POLAR.PRO software (version 5.1, Polaro-Sensors, Czech Republic) and by Multielchem software (version 3.1, J. Heyrovský Institute of Physical Chemistry of the Czech Academy of Sciences, Czech Republic) was used for voltammetric measurements. They were carried out in a three-electrode arrangement where commercially available BDDE (Windsor Scientific, UK, active surface area of $7.07 \mathrm{~mm}^{2}$, inner diameter of $3 \mathrm{~mm}$, resistivity of $0.075 \Omega \mathrm{cm}$ with a $B / C$ ratio during deposition $1000 \mathrm{ppm})$ was used as a working electrode. A saturated argent chloride electrode $(\mathrm{Agl} / \mathrm{AgCl}(\mathrm{KCl})$, sat.) served as a reference electrode and a platinum wire (diameter $1 \mathrm{~mm}$ ) (both Monokrystaly, Czech Republic) served as an auxiliary electrode.

Accumet pH-meter AB150 (Fisher Scientific, Czech Republic) was used for the $\mathrm{pH}$ measurements. All realized experiments were performed at laboratory temperature $\left(23 \pm 2{ }^{\circ} \mathrm{C}\right)$.

\section{Voltammetric measurements}

At the beginning of every series of measurements, BDDE was activated in $0.5 \mathrm{~mol} \mathrm{dm}^{-3} \mathrm{H}_{2} \mathrm{SO}_{4}$ solution by insertion of $-1000 \mathrm{mV}$ for $60 \mathrm{~s}$ and of $+2000 \mathrm{mV}$ for $60 \mathrm{~s}$. Then, the electrode surface was rinsed with deionized water. Subsequently, 20 cyclic voltammograms were realized in the potential range from -1000 to $+2000 \mathrm{mV}$. A positive regeneration potential $\left(E_{\text {reg }}\right)$ of $+2000 \mathrm{mV}$ for a regeneration time $\left(t_{\mathrm{reg}}\right)$ of $5 \mathrm{~s}$ was inserted on the used BDDE before the start of each measurement. This step provided the O-terminated surface of the BDDE for the realized measurement and, at the same time, ensured oxidation of the most of the impurities trapped on the electrode surface.
Elucidations of the supporting electrolyte effect $(\mathrm{pH})$ $\left(v=100 \mathrm{mV} \mathrm{s}^{-1}\right)$ and of the scan rate effect were realized using $\mathrm{CV}$ from $E_{\text {in }}=0 \mathrm{mV}$ to $E_{\mathrm{fin}}=+2000 \mathrm{mV}$ and reversely. Supporting electrolyte was represented either by the solution of $\mathrm{H}_{2} \mathrm{SO}_{4}(\mathrm{pH} 1)$ or by BRB (pH 2-12). The dependence of cyclic voltammograms of $\mathrm{LV}\left(c_{\mathrm{LV}}\right.$ $=5 \times 10^{-5} \mathrm{~mol} \mathrm{dm}^{-3}$ ) on the scan rate was investigated from 25 to $500 \mathrm{mV} \mathrm{s}^{-1}$ in BRB (pH 5).

DPV was applied with the following parameters (if not stated otherwise): $E_{\text {in }}=0 \mathrm{mV}, E_{\text {fin }}=+1200 \mathrm{mV}, v=40$ $\mathrm{mV} \mathrm{s}^{-1}$, pulse height $=+50 \mathrm{mV}$, pulse width $=70 \mathrm{~ms}$ (where the current values were registered in last $20 \mathrm{~ms}$ ), $\mathrm{BRB}$ of $\mathrm{pH} 3$, which was chosen based on the study, where supporting electrolyte of $\mathrm{pH}$ from 1 to 7 was employed.

The values of LOD and of LOQ were calculated as three times and ten times, respectively, a standard deviation of the blank solution divided by the calculated slope of the calibration curve [36]. The parameters of the calibration curves (i.e., slope, intercept, correlation coefficients) were calculated and all of the graphical dependences were constructed using MS Excel 365 software (Microsoft, USA). All confidence intervals were calculated at the level of significance $\alpha=0.05$.

\section{Pharmaceutical sample analysis}

A commercially available pharmaceutical preparation "LEUCOVORIN CA LACHEMA 10" (in the powder form), representing a real sample of LV, was after dissolving analyzed using DPV. The declared content was $10 \mathrm{mg}$ of LV per vial. The sample was prepared for analysis according to the manufacturer's instructions. i.e., by dissolving of the vial content in $1 \mathrm{~cm}^{3}$ of distilled water and further diluted ten times. $10 \mathrm{~mm}^{3}$ of sample solution thus prepared was added to $10 \mathrm{~cm}^{3}$ of BRB ( $\mathrm{pH} \mathrm{3}$ ). All quantitative analyses were performed by the standard addition method ( 1 addition $=20 \mathrm{~mm}^{3}$ of the standard solution of $\left.1 \mathrm{mmol} \mathrm{dm}{ }^{-3} \mathrm{LV}\right)$. The LV determination was repeated 5 times.

Acknowledgements This work was supported by the grant project of the Czech Science Foundation (project no. 17-03868S) and by The University of Pardubice (projects nos. SGSFChT_2018_003 and SD373001/82/30350(2016)).

\section{References}

1. Murray RK, Bender D, Botham KM, Kennelly PJ, Rodwell VW, Weil PA (2012) Harper's illustrated biochemistry. McGraw-Hill Lange, Columbus

2. Jolivet J (1995) Eur J Cancer 31A:1311

3. Pristoupilova K, Hermanova E, Slavik K (1973) Biochem Pharmacol 22:1937 
4. Poon MA, O'Connell MJ, Moertel CG, Wieand HS, Cullinan SA, Everson LK, Krook JE, Mailliard JA, Laurie JA, Tschetter LK, Wiesenfeld M (1989) J Clin Oncol 7:1407

5. Mini E, Trave F, Rustum YM, Bertino JR (1990) Pharmacol Ther 47:1

6. Chen XY, Liu K, Dai XJ, Zhong DF, Deng P, Ma JF (2009) J Chromatogr B 877:902

7. Vandenbosch C, Vanbelle S, Desmet M, Taton G, Bruynseels V, Vandenhoven G, Massart DL (1993) J Chromatogr Biomed Appl 612:77

8. Schleyer E, Reinhardt J, Unterhalt M, Hiddemann W (1995) J Chromatogr B Biomed Sci Appl 669:319

9. Belz S, Frickel C, Wolfrom C, Nau H, Henze G (1994) J Chromatogr B Biomed Sci Appl 661:109

10. Mandl A, Lindner W (1996) Chromatographia 43:327

11. Vantellingen O, Vanderwoude HR, Beijnen JH, Vanbeers CJT, Nooyen WJ (1989) J Chromatogr Biomed Appl 488:379

12. Meras ID, Mansilla AE, Lopez FS, Gomez MJR (2002) J Pharm Biomed Anal 27:81

13. Espinosa-Mansilla A, Meras ID, Gomez MJR, de la Pena AM, Salinas F (2002) Talanta 58:255

14. Shibukawa A, Lloyd DK, Wainer IW (1993) Chromatographia 35:419

15. Flores JR, Penalvo GC, Mansilla AE, Gomez MJR (2005) J Chromatogr B 819:141

16. Meras ID, Espinosa-Mansilla A, Gomez MJR, Lopez FS (2001) Talanta 55:623

17. Vaze VD, Srivastava AK (2007) Electrochim Acta 53:1713

18. Xiao F, Ruan C, Liu L, Yan R, Zhao F, Zeng B (2008) Sens Actuators B Chem 134:895

19. Wei SH, Zhao FQ, Xu ZY, Zeng BZ (2006) Microchim Acta $152: 285$

20. Zeng BZ, Xiao F, Ruan CP, Liu LH, Yan R, Zhao FQ (2008) Sens Actuators B Chem 134:895
21. Gurira RC, Montgomery C, Winston R (1992) J Electroanal 468 Chem 333:217

22. Bandzuchova L, Selesovska R (2011) Acta Chim Slov 58:776

23. Bandzuchova L, Selesovska R, Navratil T, Chylkova J (2011) Electrochim Acta 56:2411

24. Selesovska R, Bandzuchova L, Navratil T (2011) Electroanalysis 23:177

25. Selesovska R, Janikova-Bandzuchova L, Chylkova J (2015) Electroanalysis 27:42

26. Allen W, Pasternak RL, Seaman W (1952) J Am Chem Soc 74:3264

27. Stejskal D, Heyrovsky M (1994) Research report no. 1544-2. General Teaching Hospital, Prague

28. Selesovska R, Bandzuchova L, Navratil T, Chylkova J (2012) Electrochim Acta 60:375

29. Chylkova J, Tomaskova M, Janikova L, Selesovska R, Navratil T, Chudobova P (2017) Chem Pap 71:1047

30. Janikova-Bandzuchova L, Selesovska R, Schwarzova-Peckova K, Chylkova J (2015) Electrochim Acta 154:421

31. Selesovska R, Janikova L, Chylkova J (2015) Monatsh Chem 146:795

32. Selesovska R, Janikova L, Pithardtova K, Chylkova J, Tomaskova M (2016) Monatsh Chem 147:207

33. Cinkova K, Svorc L, Satkovska P, Vojs M, Michniak P, Marton M (2016) Anal Lett 49:107

34. Peckova K, Musilova J, Barek J (2009) Crit Rev Anal Chem 39:148

35. Peckova K, Barek J (2011) Curr Org Chem 15:3014

36. Meloun M, Militky J, Forina M (1992) Chemometrics for analytical chemistry, volume 1: PC-aided statistical data analysis, volume 2: PC-aided regression and related methods. Ellis Horwood, Chichester

\begin{tabular}{|l|lll|}
\hline Journal : Large 706 & Dispatch : 11-4-2018 & Pages : $\mathbf{8}$ \\
Article No. : $\mathbf{2 2 0 0}$ & $\square$ & $\square$ TYPESET \\
MS Code : MCCM-D-18-00085 & $\sim_{\text {CP }}$ & $\checkmark$ DISK \\
\hline
\end{tabular}

